\title{
SHORT ARTICLES
}

\section{DIAGNOSIS OF SUBACUTE SCLEROSING PANENCEPHALITIS BY SERIAL TISSUE CO-CULTIVATION}

\author{
D. R. PURDham \\ Virology Laboratory, Children's Hospital, Birmingham B16 8ET
}

\section{Plate IX}

THE presence of type-A intranuclear inclusions in brain biopsies of patients with subacute sclerosing panencephalitis (SSPE) (Dawson, 1933) first suggested a viral aetiology for this slow, demyelinating disease of the central nervous system. Later reports, describing paramyxovirus-like particles and nucleocapsids in brain biopsies (Bouteille et al., 1965; Herndon and Rubinstein, 1968), high complement-fixing and haemagglutination-inhibiting anti-measles antibody titres in serum and cerebro-spinal fluid (Connolly $e$ t al., 1967), and the detection by immunofluorescence of measles-virus antigen in brain cells (Connolly et al., 1967; Lennette, Magoffin and Freeman, 1968), all indicated an aetiological relationship between measles virus, or a closely related agent, and SSPE. This was ratified when measles virus was isolated by co-cultivating SSPE brain cells, either biopsy cells or primary cultured cells, with measles-sensitive tissue culture cells (Horta-Barbosa et al., 1969; Payne, Baublis and Itabashi, 1969).

The present report describes the application of serial co-cultivation, in conjunction with haemadsorption and immunofluorescent techniques, as a more sensitive test for the clinical diagnosis of SSPE.

\section{MATERIALS AND METHODS}

Brain biopsies from three children with clinical and serological evidence of SSPE were trypsinised, and primary monolayer tissue cultures were established by standard procedures (Parker, 1961). Mixed cell cultures were subsequently prepared from these by the method of Horta-Barbosa et al. (1969). The primary brain-cell monolayers were stripped with versene and the suspended cells were mixed with either HEp-2 cells or a continuous line of human amnion cells ( $U$ cells) in the proportion of 1 to 2 ; some of the brain cells were retained for immunofluorescence tests. When the mixed cell cultures became confluent they were held at $35^{\circ} \mathrm{C}$ for a further 7 days, and were then tested for the presence of measles antigen both by immunofluorescence and by haemadsorption-inhibition with rhesus-monkey erythrocytes and specific rabbit anti-measles serum. The mixed cultures were carried through three serial passages with fresh HEp-2 or $U$ cells and examined at each step for the appearance of measles virus.

Immunofluorescence tests were carried out on impression smears of the biopsies and on the various primary and mixed cell tissue cultures by the indirect method; cells were fixed in acetone at $-20^{\circ} \mathrm{C}$, stained with rabbit anti-measles serum and fluoresceinconjugated goat anti-rabbit-globulin serum, and viewed under ultraviolet light from an HPO 200 mercury-vapour lamp fitted with BG38 and BG12 primary filters and OG530 and GG9 secondary filters.

\section{RESULTS}

In only one of the three patients was measles antigen directly demonstrable by immunofluorescence in the brain-biopsy impression smears (fig. 1); fluorescence was seen in only a small proportion of cells and was confined to the cytoplasm. On the other hand, positive 
results were obtained in the primary brain-cell tissue cultures of all three patients; approximately $2 \%$ of cells showed cytoplasmic fluorescence; and in one case fluorescing intranuclear inclusions were also seen (fig. 2). Still higher proportions of cells were positive in the mixed cell cultures, and by the third subculture almost the entire cell population showed evidence of measles-virus replication (fig. 3).

Haemadsorption tests with monkey erythrocytes were carried out on duplicate mixed cell cultures at each passage-culture step. As many cells gave positive haemadsorption, in each case, as were stained with fluorescent antibody. Haemadsorption-inhibition with specific rabbit anti-measles serum confirmed the presence of measles virus in these cells; this was based on $75 \%$ or greater inhibition of haemadsorption.

\section{Discussion}

The results show that a negative result may often be obtained by the indirect immunofluorescence technique, when this is carried out directly on brain-biopsy smears from cases of SSPE. This could well be due to the almost inevitable contamination of the biopsy with the patients' blood. The high levels of measles antibody present in patients with SSPE, as in the present three cases, could have had a masking effect, preventing the detection of measles antigen in the biopsy cells by the rabbit antiserum used in the immunofluorescence test. For reliable diagnosis it is, therefore, important that primary tissue cultures be established from the biopsy, to be followed, if necessary, by one or more mixed cell subcultures; either immunofluorescence or haemadsorption tests may be used to detect the presence of virus.

\section{SUMMARY}

Brain biopsies from three children with SSPE were examined by indirect immunofluorescence for the presence of measles antigen, and were then serially co-cultivated with measles-sensitive tissue-culture cells. Examination of the tissue cultures by either immunofluorescence or haemadsorption proved to be more reliable for diagnosis than the direct examination of the biopsy material.

\section{REFERENCES}

Bouteille, M., Fontaine, C., Vendrenne, C. and Delarue, J. 1965. Sur un cas d'encéphalite subaigue à inclusions. Etude anatomo-clinique et ultrastructurale. Revue Neurol., $113,454$.

Connolly, J. H., Allen, I. V., Hurwitz, L. J. and Millar, J. H. D. 1967. Measles virus antibody and antigen in subacute sclerosing panencephalitis. Lancet, 1, 543.

Dawson, J. R. 1933. Cellular inclusions in cerebral lesions of lethargic encephalitis. Am. J. Path., 9, 7.

HERNDON, R. M. AND Rubinstein, L. J. 1968. Light and electron microscopy observations on the development of viral particles in the inclusions of Dawson's encephalitis (subacute sclerosing panencephalitis). Neurology, Minneap., 18, 8.

Horta-Barbosa, L., Fucillo, D. A., Sever, J. L. AND Zeman, W. 1969. Subacute sclerosing panencephalitis: isolation of measles virus from a brain biopsy. Nature, Lond., 221, 974.

Lennette, E. H., Magoffin, R. L. AND Freeman, J. M. 1968. Immunologic evidence of measles virus as an aetiologic agent in subacute sclerosing panencephalitis. Neurology, Minneap., 18, 21.

PARKER, R. C. 1961. Methods of tissue culture, 3rd ed., New York.

PAYNe, F. E., Baublis, J. V. AND ItABashi, H. H. 1969. Isolation of measles virus from cell cultures of brain from a patient with subacute sclerosing panencephalitis. New Engl. J. Med., 281, 585. 
DiAGNOSIS OF SSPE
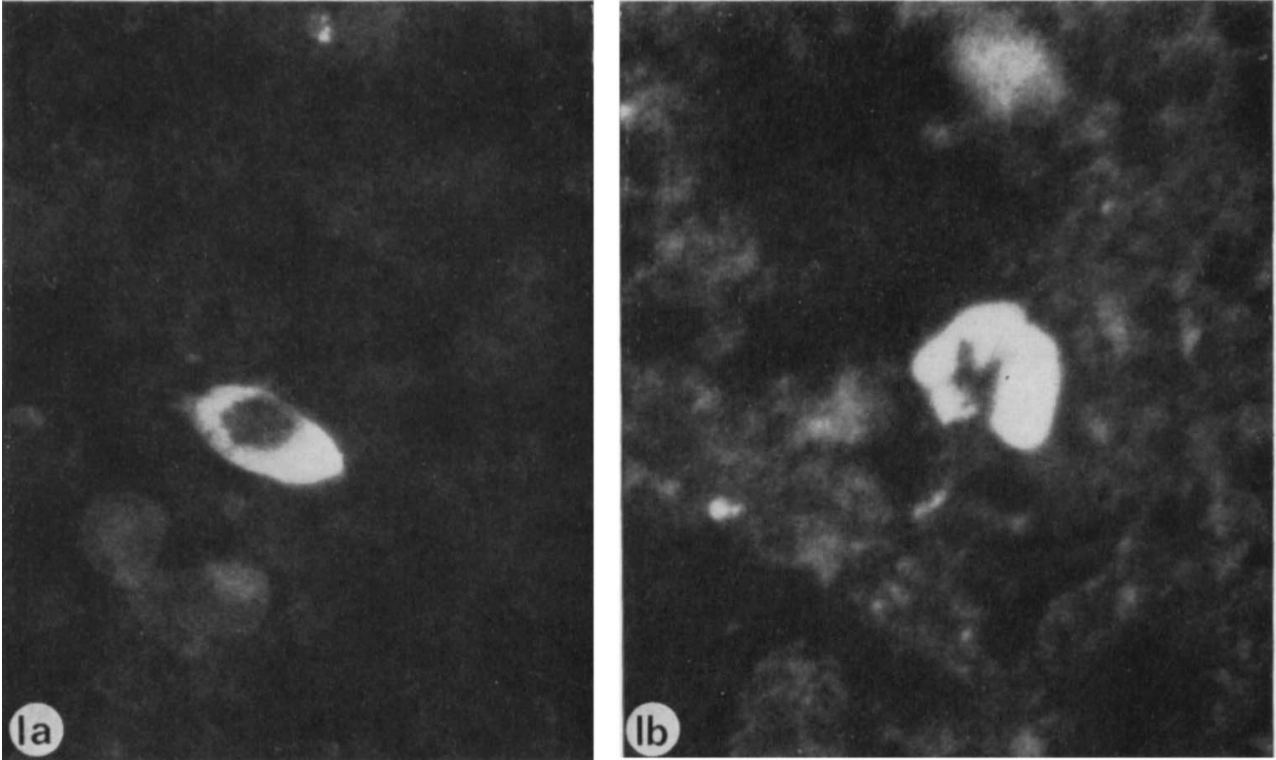

FIGS. $1 a$ and $b$.-Brain biopsy impression smears, showing intracytoplasmic accumulation of measles virus antigen. Immunofluorescence photomicrograph $(\mathrm{IF}) . \times 500$.

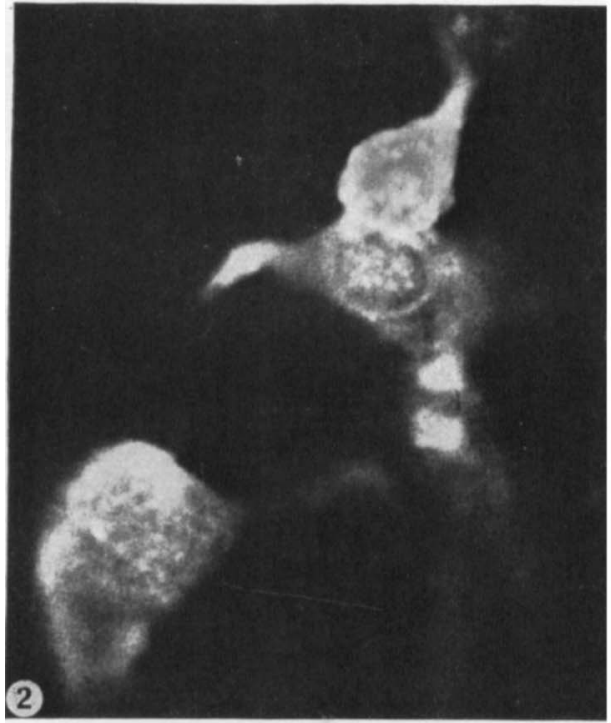

FIG. 2.-Primary tissue-culture cells grown from brain biopsy, showing measles-virus antigen and intranuclear inclusions. IF. $\times 1000$.

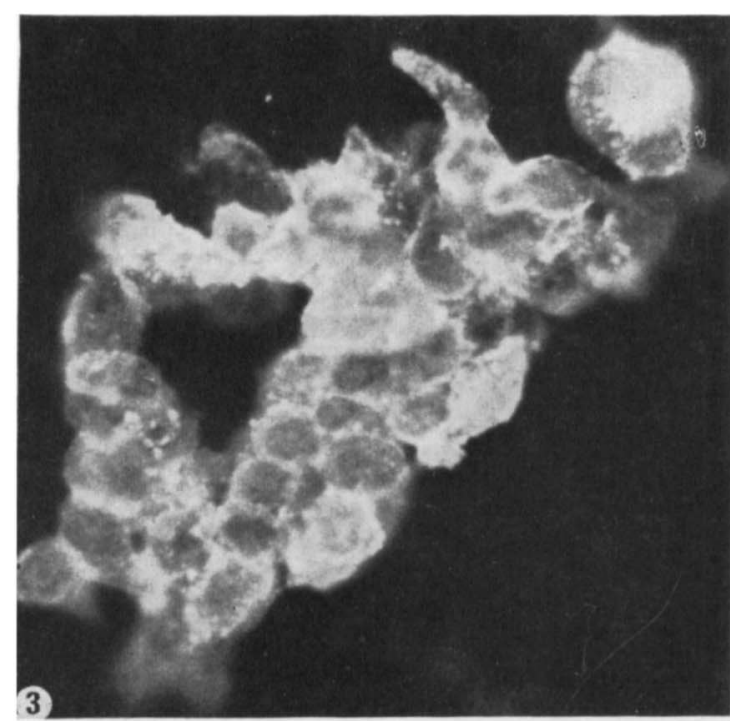

FIG. 3.-Third serial tissue-culture passage of brainbiopsy cells in co-cultivation with $\mathrm{HEp}-2$ cells IF. $\times 700$. 